\title{
HOW TO EXPLAIN THAT CHANGES IN ELDERLIES DEPRESSION LEVEL ARE UNIFORMLY DISTRIBUTED
}

\author{
Griselda Acosta \\ Doctoral Student, e-mail: gvacosta@miners.utep.edu \\ Eric D. Smith \\ Ph.D. (Systems \& Industrial Engineering), Associate Professor, e-mail: esmith2@utep.edu \\ Vladik Kreinovich \\ Ph.D. (Phys.-Math.), Professor, e-mail:vladik@utep.edu \\ University of Texas at El Paso, El Paso, Texas 79968, USA
}

\begin{abstract}
Changes in the elderlies depression level result from a large number of small independent factors. Such situations are ubiquitous in applications. In most such cases, due to the Central Limit Theorem, the corresponding distribution is close to Gaussian. For the changes in the elderlies depression level, however, the empirical distribution is far from Gaussian: it is uniform. In this paper, we provide a possible explanation for the emergence of the uniform distribution.
\end{abstract}

Keywords: elderlies depression, uniform distribution, changes in depression level.

\section{Formulation of the Problem}

Elderly depression is a serious problem. Many elderly people suffer from loneliness. In general, loneliness increases the chances of depression, and depression negatively affects the person's health. As a result, many elderly people suffer from depression; it affects every seventh elderly person - a much larger proportion than in the population in general; see, e.g., $[1,4]$.

It is therefore desirable to monitor the changes in depression level of elderly people, especially elderly people in an at-risk category. Such monitoring has indeed been undertaken; see, e.g., [2].

Changes in depression level are uniformly distributed. Depression level is usually gauged by a number on the Geriatric Depression Scale (GDS); see, e.g., $[2,4]$. The changes usually range from -8 to +8 units.

Interestingly, for any two moments of time, the corresponding changes are, in effect, uniformly distributed on the interval $\left[-d_{0}, d_{0}\right]$, where $d_{0} \approx 8$.

Why this is interesting. The uniform distribution rarely occurs in nature. The most typical probability distribution is a normal one. Its ubiquity comes from the fact that most real-life phenomena result from the joint effect of many independent small factors. In probability theory, it is known that, under reasonable conditions, 
the probability distribution of the sum of a large number of small independent random variables is close to Gaussian - the corresponding result is known as the Central Limit Theorem; see, e.g., [6]. Normal distribution is what we almost always encounter - and so the emergence of the uniform distribution is highly unusual.

The fact that we have the same uniform distribution for shorter- and longertime periods is also unusual. Indeed, as mentioned in [2], it is difficult to predict the change in one short-term period based on the observed change in another such period. With this in mind, it seems reasonable to conclude that the changes corresponding to different short-term periods are independent. The long-term difference can be represented as the sum of several such short-term differences. If all these short-term differences are uniformly distributed, the distribution of long-term differences should correspond to the sum of several independent uniform distributions. However, it is well known that the distribution of such a sum is not uniform: e.g., the distribution of the sum of two identical independent uniform distribution has a triangular probability density function. In contrast, the probability distribution of long-term differences is uniform.

How can we explain all this?

Why? In this paper, we provide a possible explanation for the emergence of this unexpected uniform distribution.

\section{Our Explanation}

Main idea. The fact that we cannot predict the change in one period based on the change in another period implies that the changes corresponding to adjacent time periods are kind of independent. On the other hand, they cannot be fully independent: if they were, then there would be a possibility that by combining almost $d_{0}$ unit changes in both periods, we would get a $2 d_{0}$ units change in the long-term period - and in the long-term period, we only observe changes from $-d_{0}$ to $d_{0}$ units.

To describe the corresponding probability distributions, we therefore need to take into account two facts:

- that these distributions are almost independent, but

- that the distribution of the sum of these two random variables is bounded by the same interval $\left[-d_{0}, d_{0}\right]$ as each of the short-term changes.

Resulting formalization. The only limitation to independence is the observed range of the values of the sum of the two random variables. It is therefore reasonable to describe the situation as maximally independent - with the restriction on the sum as the only available restriction.

In precise terms, we conclude that the probability distributions corresponding to two adjacent time intervals are not fully independent - the distribution of their sum corresponds to the distribution of the sum of two independent random variables, 
but limited to the range $\left[-d_{0}, d_{0}\right]$. In other words, the distribution for the sum can be obtained if we:

- first consider the distribution of the sum of two independent random variables each of which is distributed on the interval $\left[-d_{0}, d_{0}\right]$ and

- then we restrict this distribution to the interval $\left[-d_{0}, d_{0}\right]$, i.e., consider the conditional distribution - under the condition that the sum is located in the interval $\left[-d_{0}, d_{0}\right]$.

This formalization explains the seeming contradiction. The above formalization explains the above-mentioned seeming contradiction between:

- the fact that the long-term difference is the sum of practically independent uniformly distributed short-term differences, and

- the fact that the observed probability distribution of the long-term differences is very different from the distribution of the sum of several independent uniformly distributed random variables.

This formalization also explains the emergence of the uniform distribution. It turns out that the same formalization can explain why the distributions are uniform in the first place.

Indeed, each difference $d(t+T)-d(t)$ between depression levels at moments $t$ and $t+T$ is the sum of the large number of very-short-term differences:

$$
\begin{gathered}
d(t+T)-d(t)=(d(t+\Delta t)-d(t))+(d(t+2 \Delta t)-d(t+\Delta t))+\ldots \\
+d(t+(k+1) \cdot \Delta t)-d(t+k \cdot \Delta t))+\ldots+(d(t+T)-d(t+T-\Delta t)) .
\end{gathered}
$$

According to our formalization, the distribution of this sum should be obtained by first taking the distribution of the sum of several independent random variables $d(t+(k+1) \cdot \Delta t)-d(t+k \cdot \Delta t)$ and then limiting this distribution to the original interval $\left[-d_{0}, d_{0}\right]$.

According to the Central Limit Theorem, the distribution of the sum is close to Gaussian - and since the variance of the sum of several independent random variables is equal to the sum of the variances, this variance $\sigma^{2}$ grows with the number of variables in the sum. Thus, in our case, we select restrict to the interval $\left[-d_{0}, d_{0}\right]$ a Gaussian distribution corresponding to a very large value of $\sigma^{2}$ - and, thus, to the very large value of the standard deviation $\sigma$. On this interval, the probability density function changes from $\frac{1}{\sqrt{2 \pi} \cdot \sigma}$ to

$$
\frac{1}{\sqrt{2 \pi} \cdot \sigma} \cdot \exp \left(-\frac{d_{0}^{2}}{2 \sigma^{2}}\right) .
$$

The ratio of these two values - which is preserved when we consider conditional distributions - is thus equal to $\exp \left(-\frac{d_{0}^{2}}{2 \sigma^{2}}\right)$ which is, for large $\sigma$, very close to 1 .

Thus, under our assumption of "almost independence", the resulting probability distribution is very close to the uniform one - which is exactly what we observe. 


\title{
Acknowledgments
}

This work was supported in part by the National Science Foundation grants 1623190 (A Model of Change for Preparing a New Generation for Professional Practice in Computer Science) and HRD-1242122 (Cyber-ShARE Center of Excellence).

\section{REFERENCES}

1. Anderson D. Treating depression in old age: the reasons to be positive. Age and Ageing, 2001, vol. 30, pp. 13-17.

2. Ou J., Liang H., and Tan H.X. Identifying elderies at risk of becoming more depressed with Internet-of-Things. In: Zhou J. and Salvendy G. (eds.), Proceedings of the 4th International Conference on Human Aspects of IT for the Aged Population ITAP'2018, Las Vegas, Nevada, July 15-20, 2018, Springer Lecture Notes in Computer Science, vol. 10927, pp. 348-361.

3. Sheskin D.J. Handbook of Parametric and Nonparametric Statistical Procedures, Chapman and Hall/CRC, Boca Raton, Florida, 2011.

4. Yesavage J.A., Brink T.L., Rose T.L., Lum O., Huang V., Adey M., and Leirer V.O. Development and validation of a geriatric depression screening scale: a preliminary report. Journal of Psychiatric Research, 1983, vol. 17, pp. 37-49.

\section{КАК ОБЪЯСНИТЬ, ЧТО ИЗМЕНЕНИЯ УРОВНЯ ДЕПРЕССИИ У ПОЖИЛЫХ ЛЮДЕЙ РАСПРЕДЕЛЯЮТСЯ РАВНОМЕРНО}

\author{
Г. Акоста \\ докторант, e-mail: gvacosta@miners.utep.edu \\ Э.Д. Смит \\ к.т.н., доцент, е-mail: esmith2@utep.edu \\ В. Крейнович \\ к.ф-м.н., профессор, e-mail: vladik@utep.edu \\ Техасский университет в Эль Пасо, США
}

\begin{abstract}
Аннотация. Изменения в уровне депрессии у пожилых людей обусловлены большим количеством мелких независимых факторов. Такие ситуации широко распространены в приложениях. В большинстве таких случаев по центральной предельной теореме соответствующее распределение близко к гауссовскому. Однако, для изменений уровня депрессии у пожилых людей эмпирическое распределение далеко от гауссовского - оно однородно. В этой статье мы даем возможное объяснение появления равномерного распределения.
\end{abstract}

Ключевые слова: депрессия пожилых людей, равномерное распределение, изменения уровня депрессии. 